\title{
Effect of Aqueous Leaf Extract of Annona senegalensis on Selected Testicular Function Indices of Wistar Rats
}

\author{
Charles Obiora Nwonuma ${ }^{1, ~}$, Emenike Onyebum Irokanulo ${ }^{1}$, Adeyemi Eunice Jolaiya ${ }^{1}$, \\ Ayokanmi Ore ${ }^{2}$ \\ ${ }^{1}$ Biochemistry Unit, Department of Biological Sciences, College of Science and Engineering, Landmark University, Omuaran Kwara State, \\ Nigeria \\ ${ }^{2}$ Biochemistry Unit, Department of Chemical Sciences, Faculty of Natural Sciences, Ajayi Crowther University, Oyo, Oyo State, Nigeria
}

\section{Email address:}

charlesdetermination@gmail.com (C. O. Nwonuma), eoirokanulo@yahoo.co.uk (E. O. Irokanulo), joladeyemi1@yahoo.com (A. E. Jolaiya), oreayokanmi@gmail.com (A. Ore)

\section{To cite this article:}

Charles Obiora Nwonuma, Emenike Onyebum Irokanulo, Adeyemi Eunice Jolaiya, Ayokanmi Ore. Effect of Aqueous Leaf Extract of Annona senegalensis on Selected Testicular Function Indices of Wistar Rats. American Journal of Life Sciences. Vol. 3, No. 3, 2015 , pp. $203-212$. doi: 10.11648/j.ajls.20150303.21

\begin{abstract}
This study evaluated the effect of Annona senegalensis on selected biochemical and testicular function indices in rats. Twenty Wistar rats $(125-127 \mathrm{~g})$ were randomly assigned into four experimental groups: A, B, C and D, ( $\mathrm{n}=5 / \mathrm{group}$ ). Animals in group A served as control and was administered distilled water, while animals in groups B, C, and D were given 100 $\mathrm{mg} / \mathrm{kg}$ body weight (bw), $200 \mathrm{mg} / \mathrm{kg}$ bw and $300 \mathrm{mg} / \mathrm{kg}$ bw of aqueous leaf extract of Annona senegalensis (ALEAS) respectively by oral gavage for 21 days. Data revealed a significant decrease $(P<0.05)$ in the testis-body weight ratio and total protein content in the testes of rats administered ALEAS compared to the control. There was also a significant increase $(P<0.05)$ in testicular cholesterol, glycogen, malondialdhyde (MDA) and catalase (CAT) activity. Additionally, histopathological studies revealed a marked degeneration of seminiferous tubules. Overall, data from the present study suggest that aqueous leaf extract of Annona senegalensis may possess the potential to adversely affect testicular function in rat.
\end{abstract}

Keywords: Annona senegalensis, Testes, Testicular Function, Histopathology, Rat

\section{Introduction}

Annona senegalensis is a subtropical plant [1] that has been implicated for the treatment of chest pain, coughs, anaemia, urinary tract infection $[2,3]$, cancer treatment $[4,5]$, diarrhoea, dysentery $[6,7]$, anthritis and rheumatism $[8,9]$. The plant has also been shown to be effective as an antiulcer/antacid, smooth muscle relaxant [10], antibacterial [3], antiprotozoal [11], molluscicidal [12] and hormonal activities [13]. It can be used as a pain reliever, a stimulant, and antihelmintic $[14,15]$. There are unsubstantiated claims that the plant is being used locally to enhance sexual performance and boost fertility in male. The rate of spermatogenesis and the quality of the sperm is necessary for fertility in a man. The testis which is always in pair in human are responsible for the production of semen which contain the sperm cell. Albeit, studies showing the effect of Annona senegalensis on the testicular functions are limited, hence this present study was to evaluate the effect of aqueous leaf extract of Annona senegalensis on selected testicular function indices.

\section{Materials and Methods}

\subsection{Chemicals and Reagents}

The following substances were employed: Epinephrine, and hydrogen peroxide $\left(\mathrm{H}_{2} \mathrm{O}_{2}\right)$, (Sigma ${ }^{\circledR}$ Chemical Company, London, UK); Assay kits for Total Cholesterol (RANDOX ${ }^{\circledR}$ Laboratories Ltd., Antrim, UK). All other reagents used in the study were of analytical grade and highest purity.

\subsection{Plant Material and Authentication}

Annona senegalensis leaves were collected from Landmark University farm at Omu-aran. They were identified and authenticated at the Herbarium of the Department of Plant biology, Faculty of Life Science, University of Ilorin. The plant was assigned a voucher number UIH002/1084. 


\subsection{Preparation of the Aqueous Leaf Extract of Annona senegalensis (ALEAS)}

Annona senegalensis leaves were washed with clean water and air dried at room temperature. The leaves were milled into powder; $500 \mathrm{~g}$ of the powder was macerated in one litre of distilled water for 24 hours. The mixture was filtered and the filtrate were concentrated using rotary evaporator at $60 \mathrm{oC}$. The concentrated filtrate were collected in a bottle and kept at room temperature before used. The concentrate was reconstituted in distilled water to prepare the various doses of ALEAS used in the study.

\subsection{Animal Selection and Care}

Twenty male Wistar rats weighing between 125 and $127 \mathrm{~g}$ were procured from the Experimental Animal Unit of the Department of Biological Sciences, Landmark University, Omu-aran Nigeria. They were acclimatized under laboratory conditions prior to the commencement of experiment. The animals were housed in wire-meshed cages and provided with food and water ad libitum. The animals were kept at standard conditions of temperature and humidity with $12 \mathrm{~h}$ light/dark cycles. They were fed with commercial rat diet. Handling of the experimental animals also conforms to international guidelines on the care and use of laboratory animals (National Research Council) [16].

\subsection{Animal Grouping}

The animals were randomly grouped into A, B, C, and D. Animals in group A served as control and were administered $0.5 \mathrm{~mL}$ distilled water, while animals in groups group B, C, and D were administered 100, 200 and $300 \mathrm{mg} / \mathrm{kg}$ body weight (bw) respectively of the aqueous leaf extract of Annona senegalensis (ALEAS) by oral gavage. The respective doses of ALEAS were delivered in $0.5 \mathrm{~mL}$ solution once daily for a period of 21 days.

\subsection{Animal Sacrifice and Preparation of Testicular Homogenates}

The animals were sacrificed under mild diethyl ether anaesthetization 24 hours after cessation of last treatment. The testes were removed and dropped into an isotonic solution, the testes were weighed and homogenized in ice cold $0.25 \mathrm{M}$ sucrose solution $(1: 5 \mathrm{w} / \mathrm{v})$. The homogenates were centrifuged at $1500 \times \mathrm{g}$ for 10 minutes in a refrigerated centrifuge TDL-5000B, centrifuge (Shanghai Anke company, Ltd., China). The supernatant was collected and stored frozen.

\subsection{Estimation of Biochemical Indices}

Total protein in testicular homogenate was determined by the method of Gornall et al. [17]. Catalase (CAT) activity was determined according to the method described by Sinha [18]. The superoxide dismutase (SOD) activity was determined by the method described by Misra and Fridovich [19]. Thiobarbituric acid reactive substances (TBARS) was measured as an estimate of malondialdhyde (MDA) which is a product of lipid peroxidation using the method described by Satoh [20]. Glycogen content in the testes was determined by the method described by Kemp et al. [21]. The concentration of total cholesterol in the testes was analysed using reagent assay kit according to the method of Fredrickson et al. [22]. Both acid phosphatase (ACP) and alkaline phosphatase activities (ALP) were determined by the method described by Wright et al. [23, 24].

\subsection{Histological Examination}

The preparation of tissues for histological examination was done as described by Adeyemi and Akanji [25]. The representative portions of the testes removed from sacrificed rats were fixed in $10 \%$ buffered formalin $(\mathrm{pH} \mathrm{7.4)}$ for $12 \mathrm{hrs}$, then embedded in paraffin. The paraffin embedded tissues were cut into $5-\mu \mathrm{m}$ sections. The tissue sections were deparaffinised and stained with haematoxylin and eosin. The stained sections were viewed under light microscope and were captured using Bresser DSC-W35 (Meade instruments, Berlin, Germany)

\subsection{Data Analysis}

Data were analysed using one way ANOVA, followed by Duncan post hoc mean comparison test which was used to assess for significant differences between variables. The analysed data were presented as mean of five replicates \pm standard error of mean (SEM). P-values less than 0.05 ( $\mathrm{P}<$ $0.05)$ were considered statistically significant. All statistical analyses were done using the Statistical Package for Social Science (IBM SPSS Statistics 19).

\section{Results}

\subsection{Phytochemical Constituents of ALEAS}

The phytochemical analysis carried out on ALEAS indicated the presence of steroids, terpenoids, anthraquinone, tannins and flavonoids.

\subsection{Effect of ALEAS on Testis - Body Weight Ratio and Testicular Total Protein in Rat}

There was a significant decrease $(P<0.05)$ in the testesbody ratio in the groups treated with ALEAS in a dose dependent fashion when compared to the control (Fig. 1). Similarly there was a decrease in the total testicular protein concentration in group administered various doses of but only found significant in the group administered $300 \mathrm{mg} / \mathrm{kg}$ of the ALEAS (Fig 2).

\subsection{Effect of ALEAS on Testicular Cholesterol, Glycogen and MDA Content in Rat}

There was a significant increase $(\mathrm{P}<0.05)$ in the testicular total cholesterol (Fig.3) and testicular glycogen (Fig 4) in all the test groups compared to control group. Administration of ALEAS also caused a significant increase in testicular 
malondialdehyde concentration in a dose dependent manner (Fig. 5).

\subsection{Effect of ALEAS on Testicular SOD and CAT Activities in Rat}

Activities of testicular enzymic antioxidants, SOD and CAT were increased in a dose - dependent manner following the administration of various doses of ALEAS compared to the control (Fig 6 and 7).

\subsection{Effect of ALEAS on Testicular ALP and ACP Activities in Rat}

Fig. 8 and Fig. 9 represent the influence of different doses of ALEAS on testicular ALP and ACP activities in rat. An increase in both ALP and ACP activities were observed in the ALEAS - treated groups compared to control, although, not significantly different from control $(\mathrm{P}<0.05)$

\subsection{Effect of ALEAS on Testicular Histology in Rat}

Histopathological data showed a marked degeneration of the seminiferous tubules (Fig. 10). The tissue degeneration were dose dependent with more effect in the group treated with $300 \mathrm{mg} / \mathrm{kg}$ bw ALEAS.

\section{Discussion}

The various parameters investigated in this study are useful indices of evaluating testicular function in experimental animals [26]. A reduction in testis-body weight ratio (Fig.1) observed in the rats administered with the leaf extract suggests the degenerating capacity of ALEAS and this reduction may due to inhibition of seminiferous tubule fluid formation and loss of germ cells by direct inhibition on spermatogenesis. Our observation regarding reduction in testis - body weight ratio agrees with earlier report on rats [27] and mice [28]. Testicular secretory constituents like protein, cholesterol, sialic acid and glycogen can be used to determine the functional capacity of the testes [29, 30, 31]. Cholesterol is normally secreted into the seminal plasma by the prostate [32] and its function is to protect the spermatozoa against environmental shock. The increase in testicular cholesterol (Fig. 3) in this experiment could be as a result of the alteration in the distribution of lipids in the gonad and increased mobilization from the membrane of testicular cells or increased prostatic secretion of cholesterol into the seminal plasma [33]. The increase in the cholesterol could also result from phagocytosis of sertoli cells hence leaving behind the lipid of the cell membrane [34]. High level of testicular cholesterol has been linked to inhibition of androgen synthesis by leydig cell. Leydig cells release a class of hormones called androgens: testosterone, androstenedione and dehydroepiandrosterone (DHEA), when stimulated by pituitary luteinizing hormone ( $\mathrm{LH})$. $\mathrm{LH}$ increases the activity of the enzyme cholesterol desmolase stimulating synthesis and secretion of testosterone by the Leydig cells [35].

The increase in glycogen (Fig.4) which is the testicular source of glucose could be as a result of interruption in the glucose metabolism or of glucose transport which is the main source of energy for the synthesis of protein in the germinal cells. Glucose transporters are the main transport pathway of glucose to the seminiferous tubules (STs) and spermatogonia [36]. The degeneration caused by the ALEAS could have resulted in the interruption of glucose metabolism and ultimately lipid accumulation in the cytoplasm of the cells especially those located close to lumen of the seminiferous tubules. Malondialdhyde is a metabolic product of a lipid peroxidation. Excessive lipid peroxidation destroys the structure of lipid matrix in the membranes of spermatozoa, and may lead to loss of sperm cell motility [37]. The marked increase in the concentration of testicular MDA (Fig.5) may be due to promotion of peroxidation of testicular membrane lipids by the extract. The antioxidant enzymes such as SOD and CAT are always mobilized against free radicals that may cause lipid peroxidation. SOD is present various cell types where it scavenges superoxide radicals and protects cells from oxidative damage. It has been shown that the activity of antioxidant enzymes behaves in two different ways during oxidative stress. At the beginning of stress, this activity increases, while in the long term, it is reduced due to the massive production of free radicals. This reduction is the result of damage to the molecular principles that is required to induce these enzymes [38, 39]. The non - significant increase in the SOD activity (Fig. 6) could be due to progressive damage to the molecular machinery that is require to induce this enzyme. CAT is efficient antioxidant enzyme and it reduces $\mathrm{H} 2 \mathrm{O} 2$ formed in cells to water and molecular oxygen, and it is not saturated by $\mathrm{H} 2 \mathrm{O} 2$ at any concentration [40]. The significant increase in catalase activity (Fig. 7) could be in response to an increase in reactive oxygen species due to oxidative stress induced by ALEAS. ALP is involved in mobilizing carbohydrates and lipid metabolites to be utilized either within the cells of the accessory sex structures or by the spermatozoa in the seminal fluid [41]. ACP is widely distributed in the testes and is important in the physiology of sperm [42]. Administration of the graded doses of ALEAS did not show any significant increase in the activities of ALP and ACP (Fig 8 and 9) which may imply that the functions of the enzyme were not significantly altered by the extract during the duration of administration. The histopathological result (Fig 10) showed tissue degenerating effect that was in a dose dependent manner with the group with highest doses showing more degree of degeneration. The extract might have induced apoptosis which is consistent with the histological changes and tissue degeneration [43]. The photomicrograph also revealed a marked depletion of seminiferous tubules and other testicular cells. 


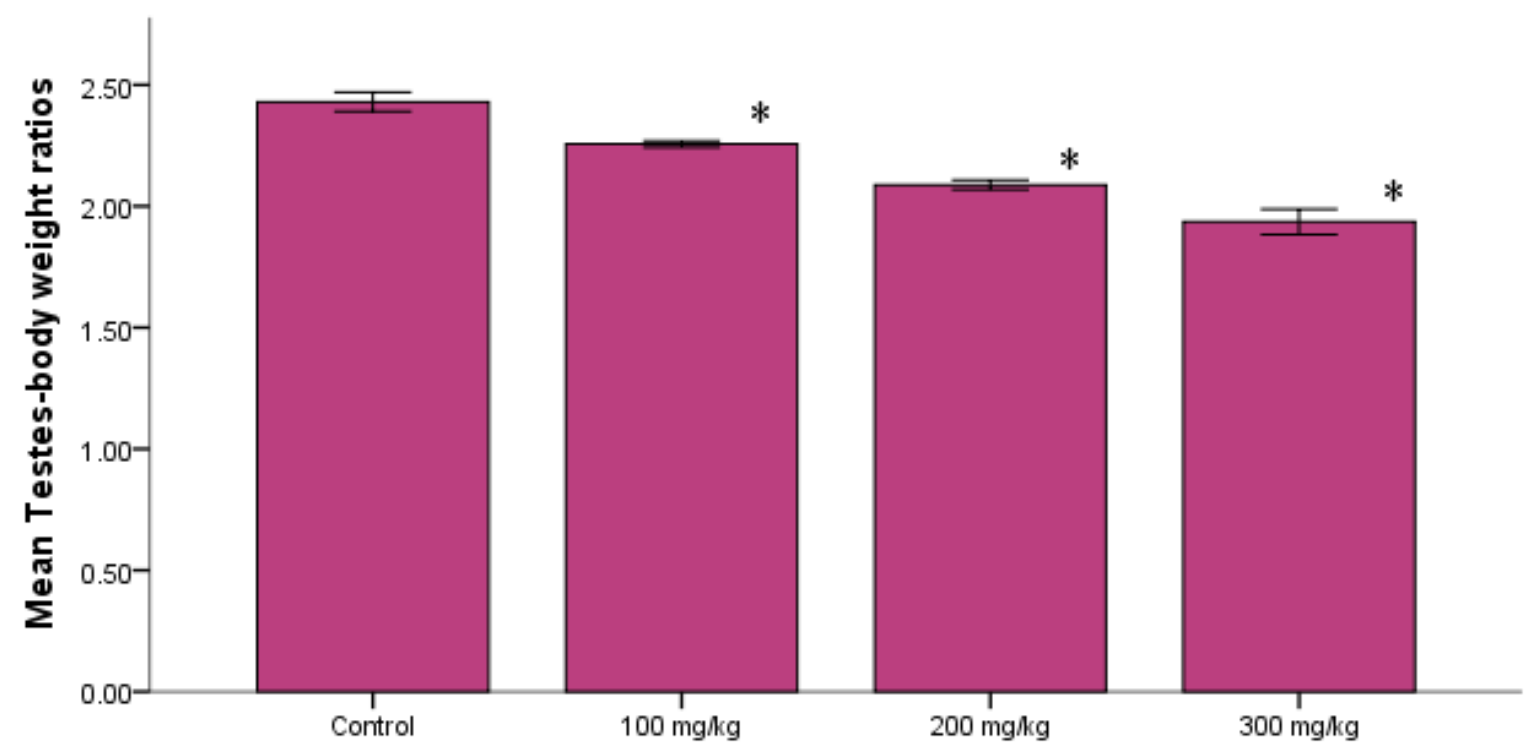

\section{Group}

Fig. 1. Effect of varying doses of aqueous leaf extract of Annona senegalensis on the testes-body weight ratio of the rats. Each value is represented as mean of five replicates \pm SEM. * Statistical difference relative to control at $P<0.05$.

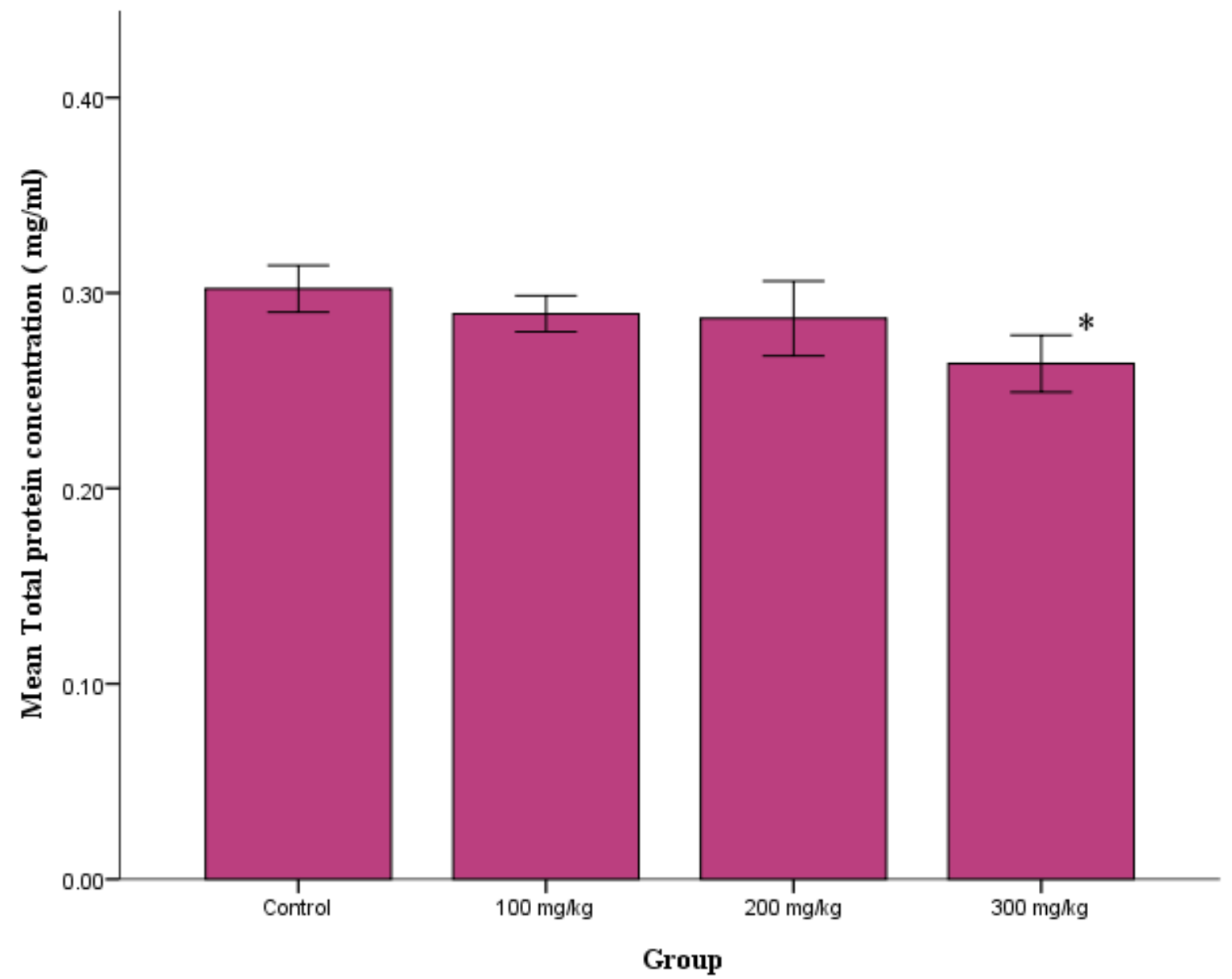

Fig. 2. Effect of varying doses of aqueous leaf extract of Annona senegalensis on the testicular total protein concentration in the rats. Each value is represented as mean of five replicates $\pm S E M$. * statistical difference relative to control at $P<0.05$. 


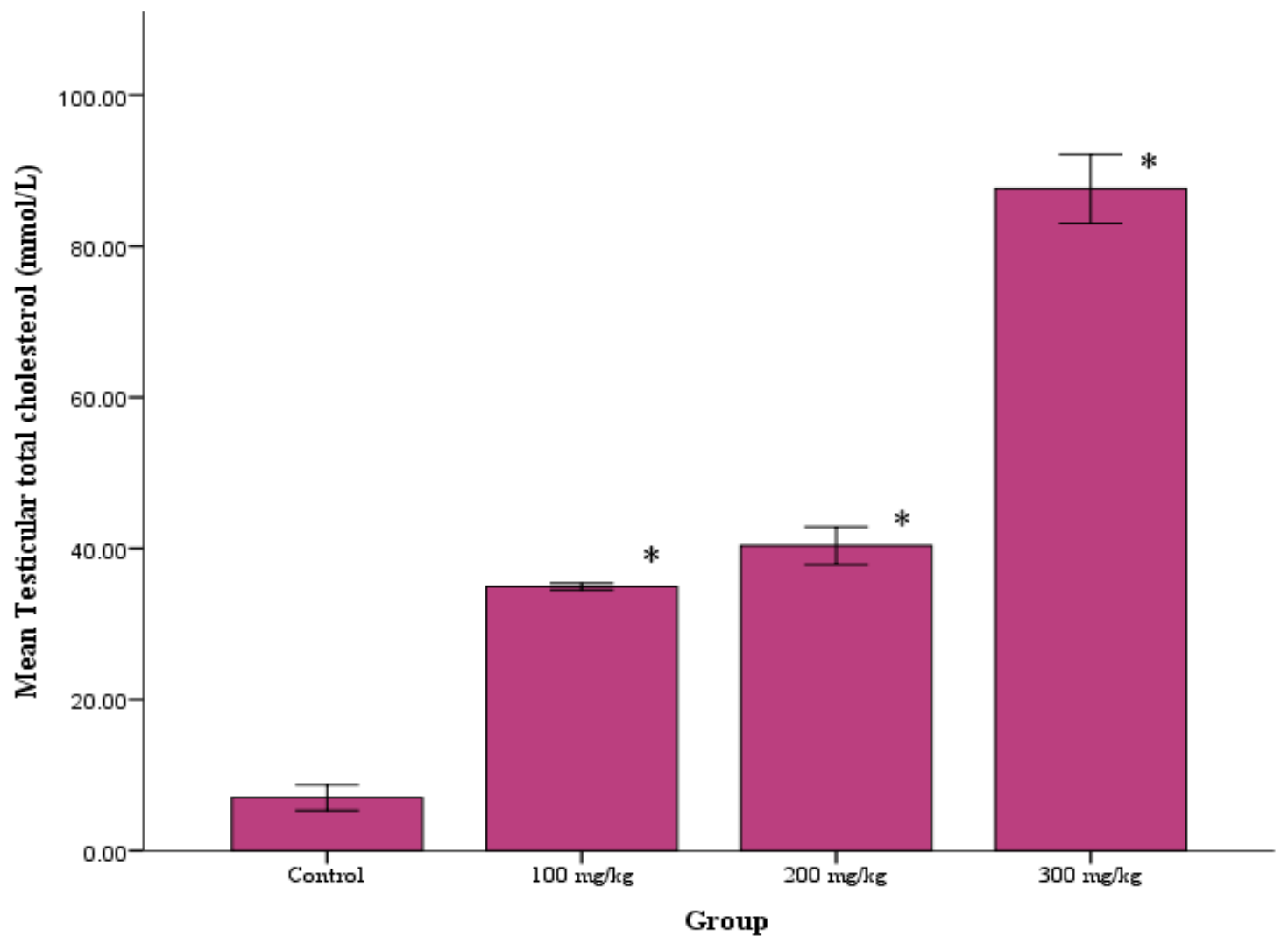

Fig. 3. Effect of varying doses of aqueous leaf extract of Annona senegalensis on the testicular total cholesterol in the rats. Each value is represented as mean of five replicates $\pm S E M . *$ statistical difference relative to control at $P<0.05$.

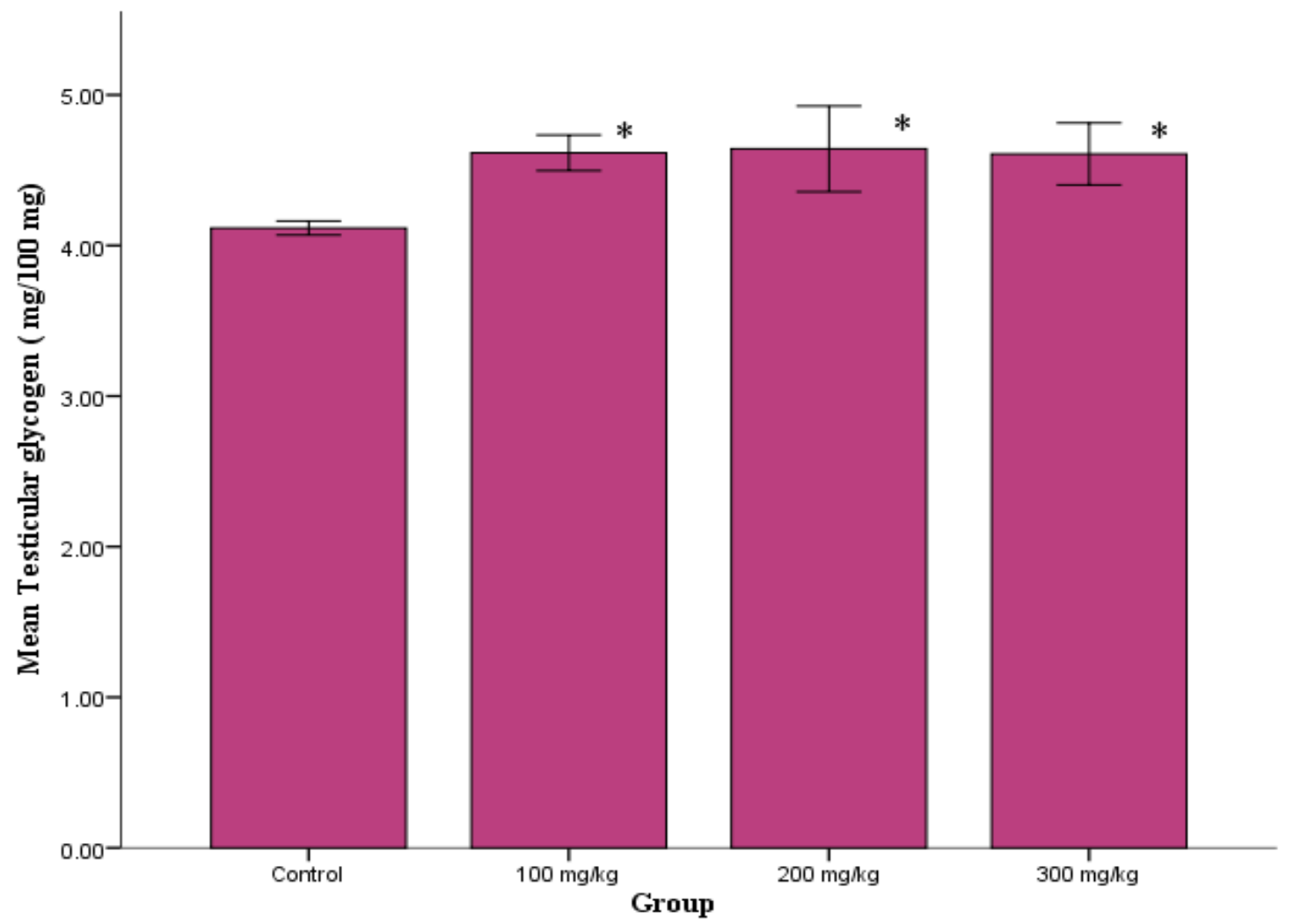

Fig. 4. Effect of varying doses of aqueous leaf extract of Annona senegalensis on the testicular total glycogen in the rats. Each value is represented as mean of five replicates \pm SEM. * statistical difference relative to control at $P<0.05$. 


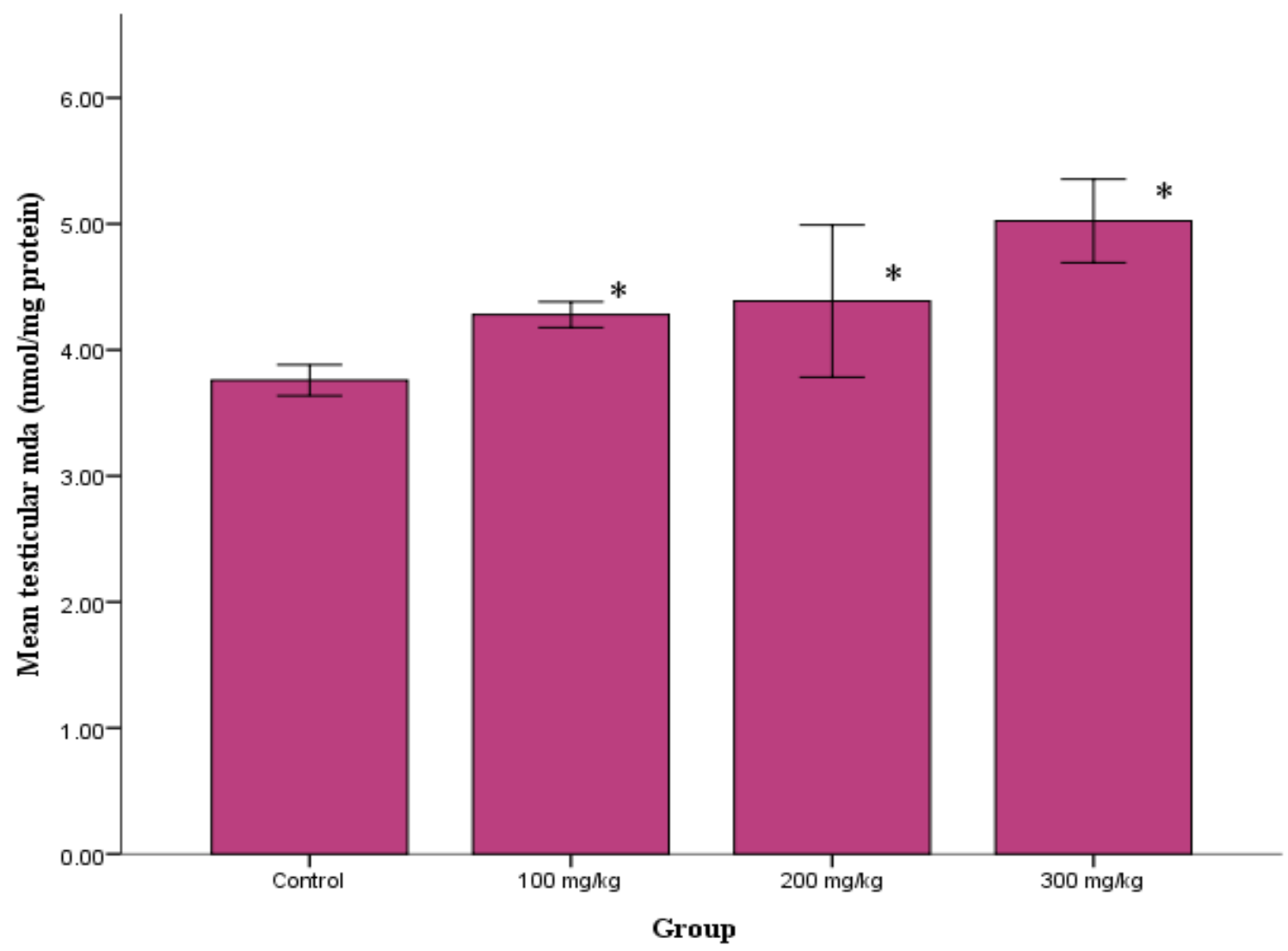

Fig. 5. Effect of varying doses of aqueous leaf extract of Annona senegalensis on the testicular malondialdhyde in the rats. Each value is represented as mean of five replicates $\pm S E M . *$ statistical difference relative to control at $P<0.05$.

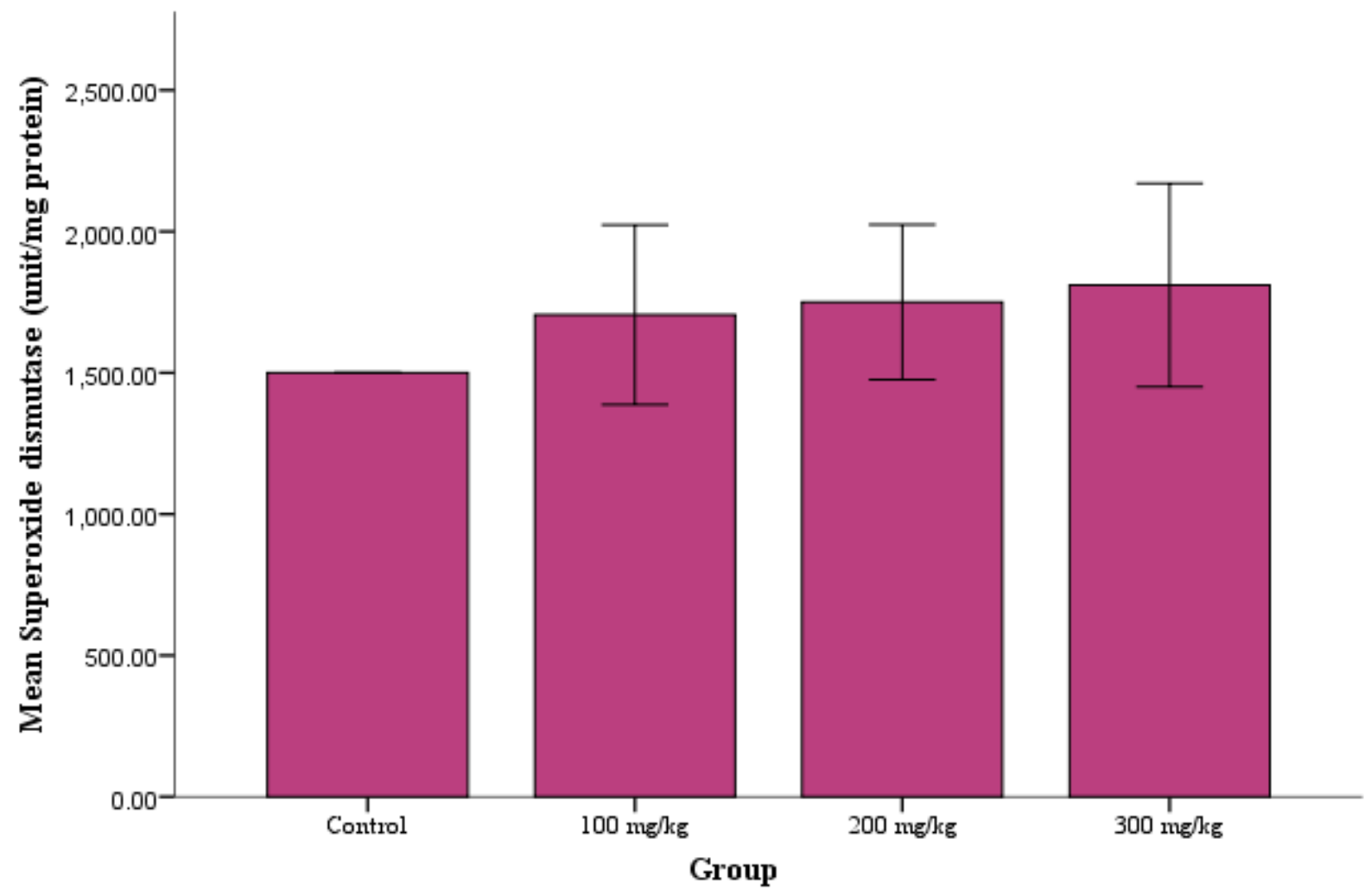

Fig. 6. Effect of varying doses of aqueous leaf extract of Annona senegalensis on the testicular malondialdhyde in the rats. Each value is represented as mean of five replicates \pm SEM. * statistical difference relative to control at $P<0.05$. 


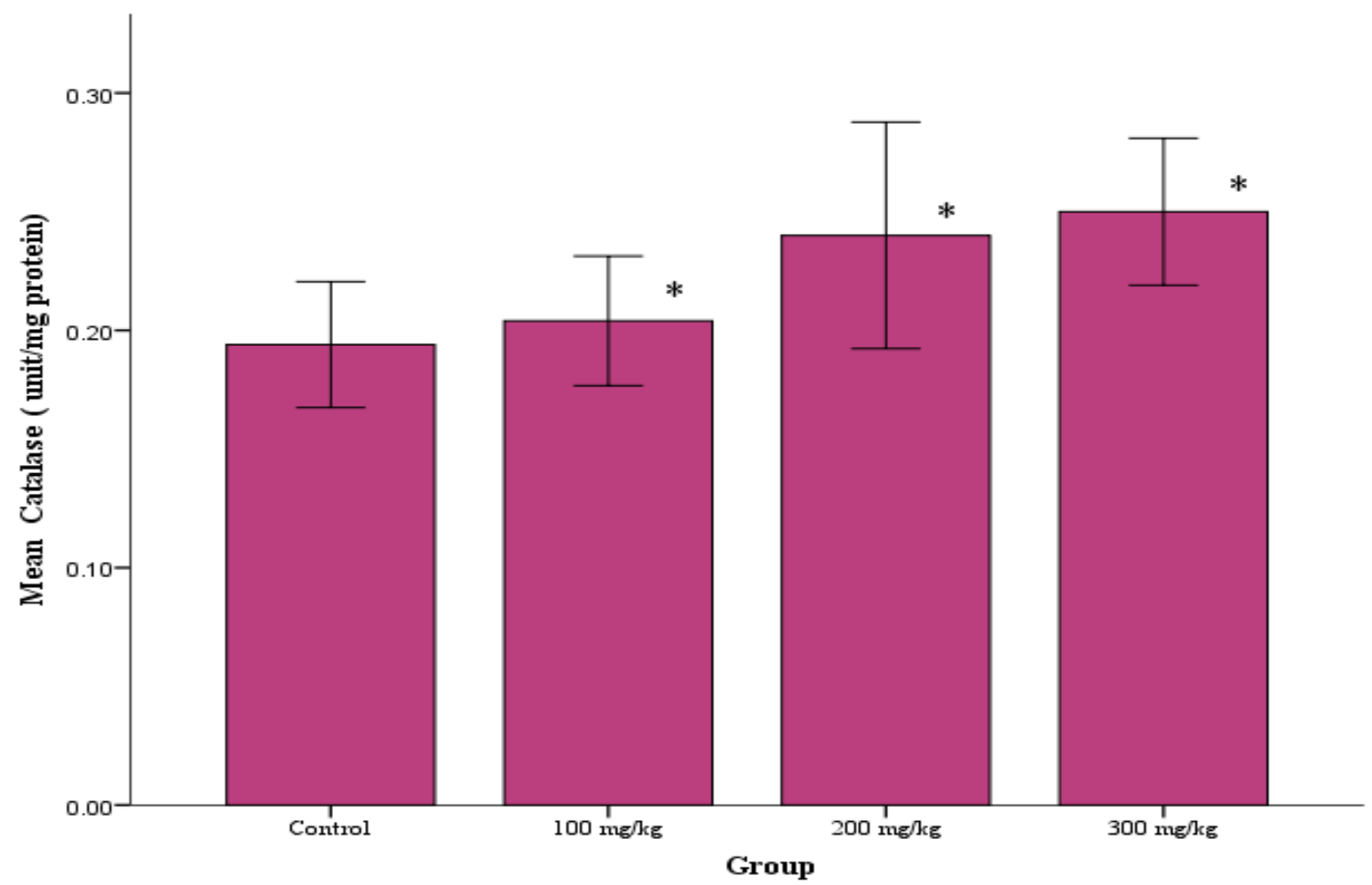

Fig. 7. Effect of varying doses of aqueous leaf extract of Annona senegalensis on superoxide dismutase activity in the rats testes. Each value is represented as mean of five replicates $\pm S E M$. * statistical difference relative to control at $P<0.05$.

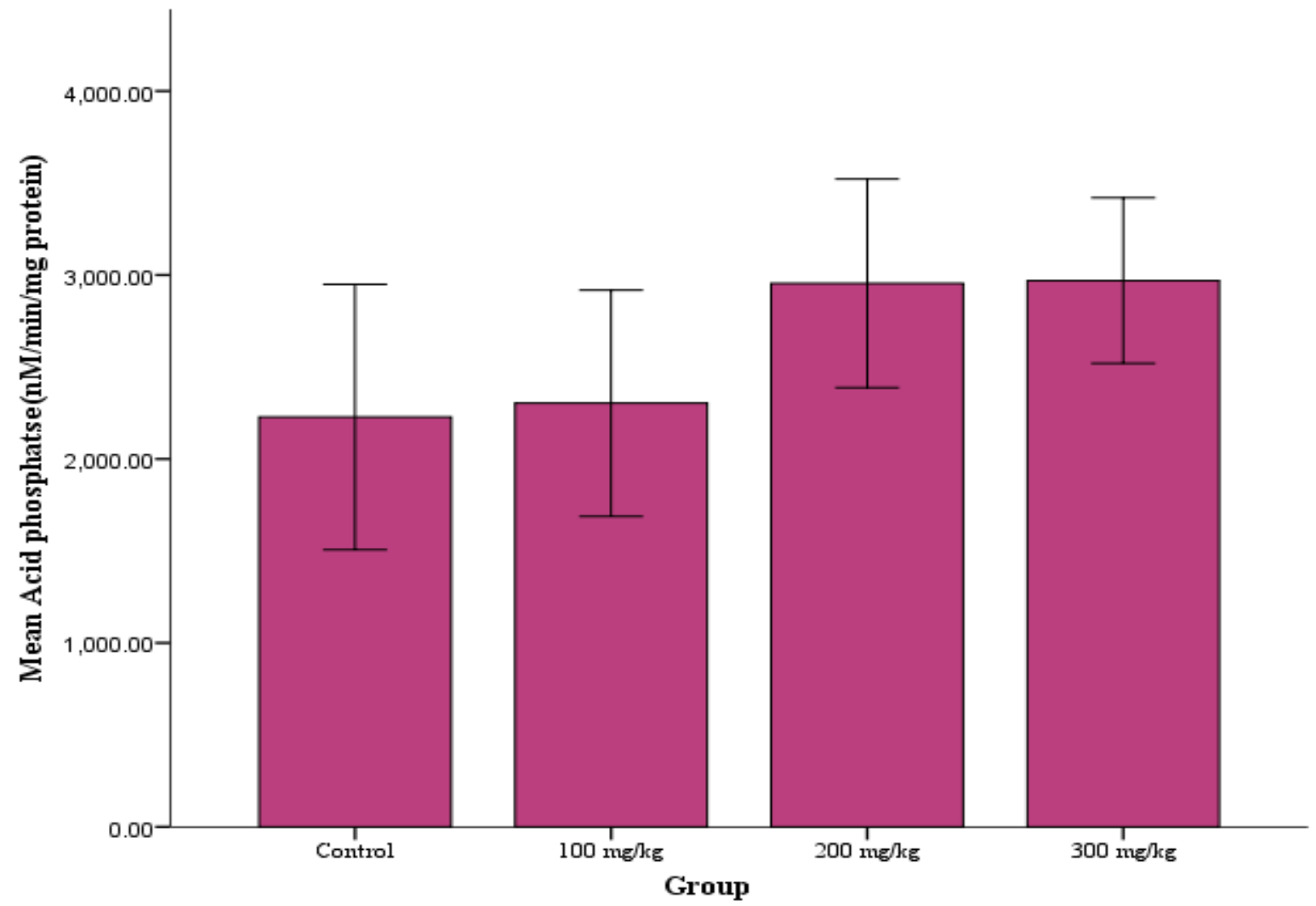

Fig. 8. Effect of varying doses of aqueous leaf extract of Annona senegalensis on Acid phosphatase activity in the rats testes. Each value is represented as mean of five replicates \pm SEM. * statistical difference relative to control at $P<0.05$. 


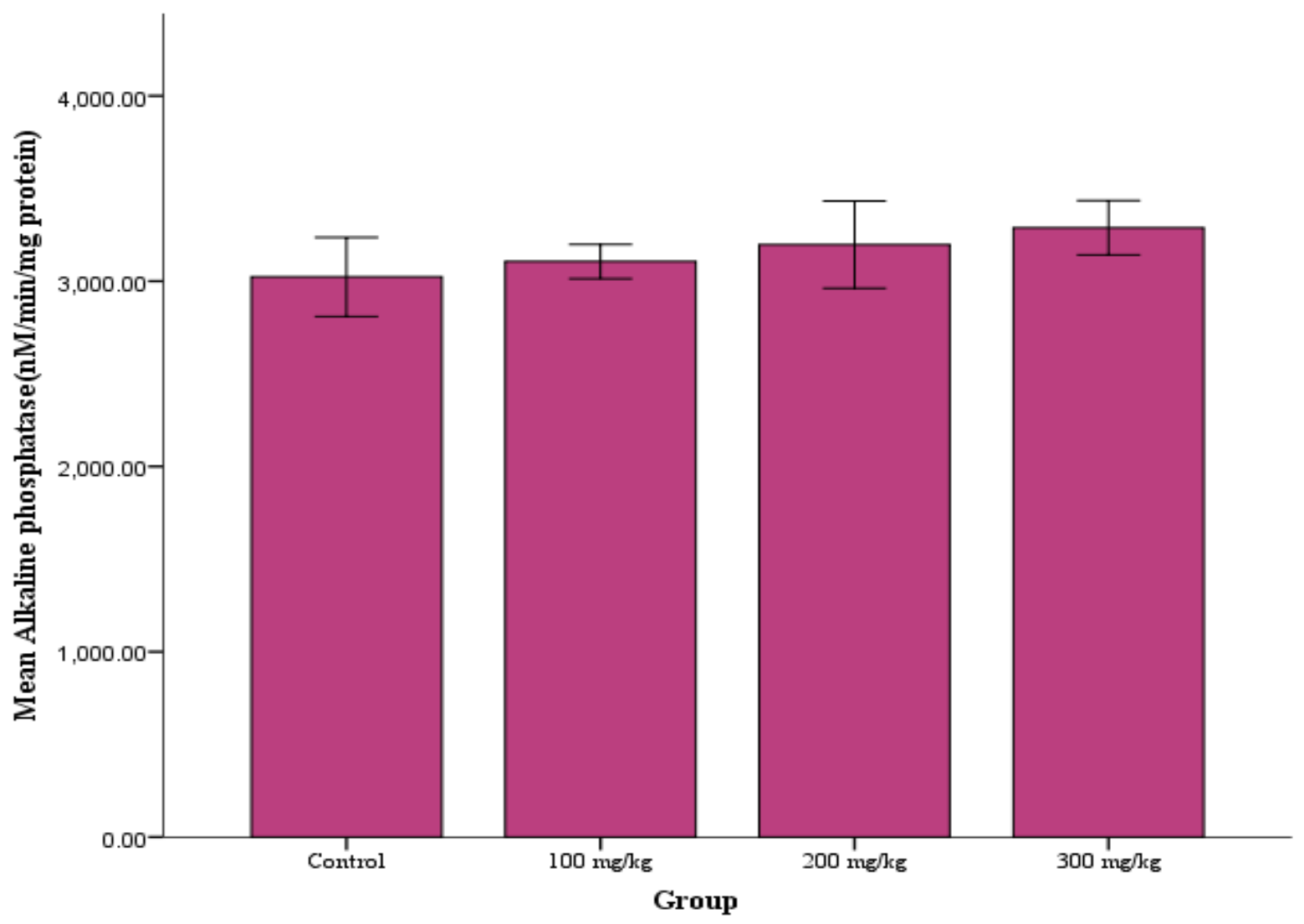

Fig. 9. Effect of varying doses of aqueous leaf extract of Annona senegalensis on Alkaline phosphatase activity in the rats testes. Each value is represented as mean of five replicates \pm SEM. * statistical difference relative to control at $P<0.05$.

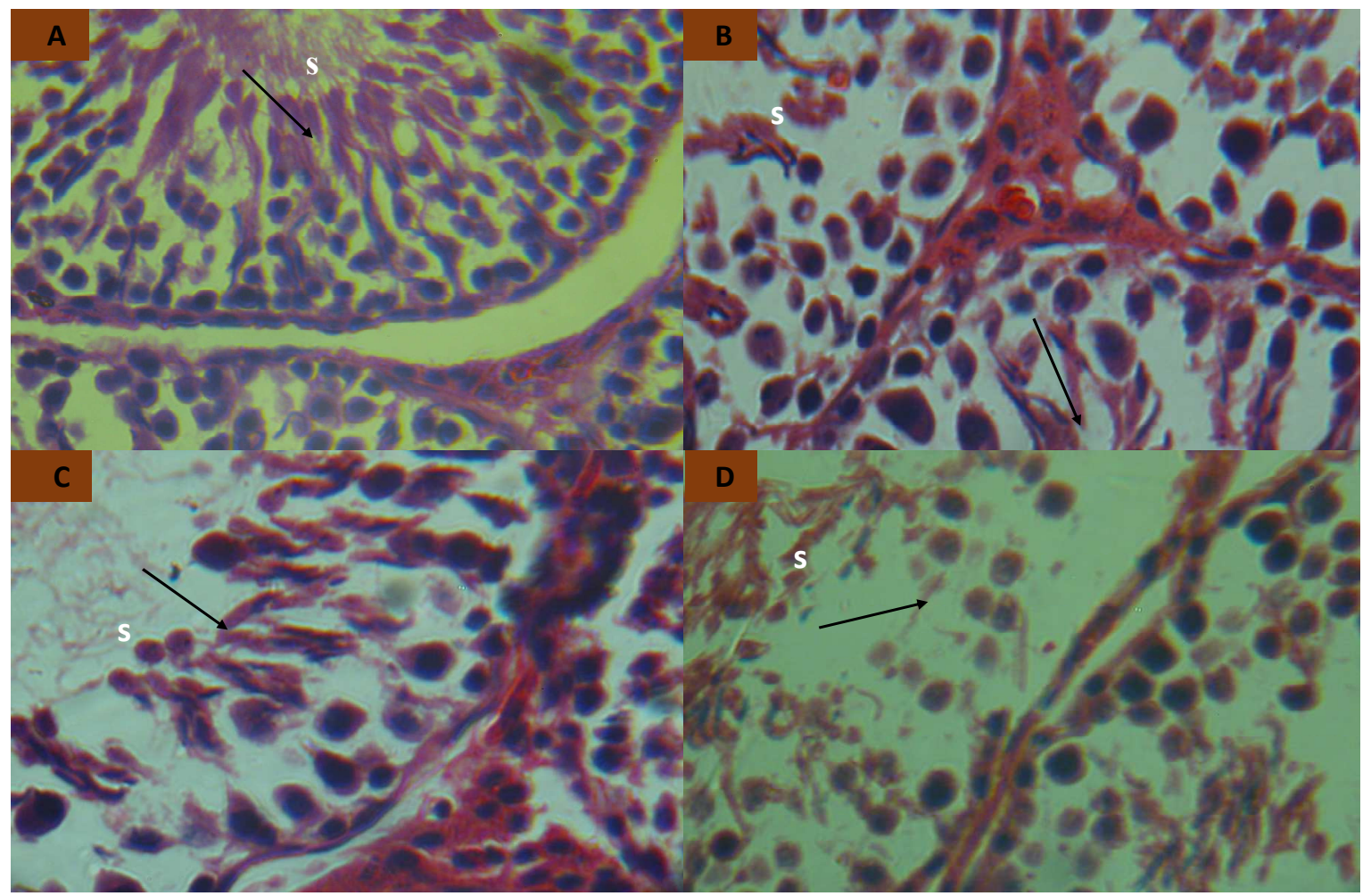

Fig. 10. Photomicrographs ( $\times 400, H \&$ E) of rat testes (A) Group administerd with distilled water (Control); showed testicular tissue with active seminiferous tubules containing cells at various stages of development (spermatogenic series). The cells are normochromic and normocytic. (B) Group administered with $100 \mathrm{mg} / \mathrm{kg}$; showed seminiferous tubules with wider lumen. (C) administered with 200mg/kg; showed mildly depleted seminiferous tubules dilated and congested vascular channels. (D) Group administered with $300 \mathrm{mg} / \mathrm{kg}$; showed completely depleted seminiferous tubules. 


\section{Conclusion}

In the present study, we have established that aqueous leaf extract of Annona senegalensis is capable of causing alterations in some biochemical and testicular function parameters considered. These alterations are mostly dose dependent, and are likely indications that the extract may not be completely safe for oral medications.

\section{References}

[1] C. O. Okoli, C. A. Onyeto, B. P. Akpa, A. C. Ezike, P. A. Akah and T. C. Okoye, "Neuropharmacological evaluation of Annona senegalensis leaves," Afr. J. Biotechnol., 9, (49), 8435-8444, 2010.

[2] H. M. Burkill, "The Useful Plants of West Africa," Royal Botanical Gardens, Kew, pp. 103-105, 1985.

[3] D. N. Muanza, B. W. Kim, K. L. Euler and L. Williams, "Antibacterial and antifungal activities of nine medicinal plants from Zaire," Int'1 J. Pharmacog. 32, 337-345, 1994.

[4] J. I. Durodola, "Viability and transplanability of developed tumour cells treated in vitro with antitumour agent C/M2 isolated from herbal cancer remedy of Annona senegalensis," Planta Medica, 28, 359, 1975.

[5] M. O. Fatope, H. Ibrahim, and Y. Takeda, "Screening of higher plants reputed as pesticides using the brine shrimp lethality assay," Int'l J. Pharmacog. 31, 250-254, 1993.

[6] T. O. E. Ekpendu, O. D. Obande, P. O. Anyogo and A. D. Attah, "Nigerian ethnomedicine and medicinal plant flora - the Benue experience part 1". J. Pharm. Res. Dev., 3, 37-46, 1998.

[7] A. C. Kudi and S. H. Myint, "Antiviral activity of some Nigerian medicinal plant extracts," J. Ethnopharmacol, 68, 289-294, 1999.

[8] J. Audu, "Medicinal herbs and their uses in Bauchi State," The Nig Field, 54, 157-168, 1989.

[9] J. M. Dalziel, "The useful plants of West Tropical Africa," Crownoverseas agents for the colonies," London. pp. 2-3, 1937.

[10] R. B. F. Langason, D. N. Akunyili, and P. I. Akubue, "A Preliminary study of the gastrointestinal effects of some Nigerian medicinal plants," Fitoterapia, 65, 235-240, 1994.

[11] A. G. Igweii and A. O. Onabanjo, "Chemotherapeutic effects of Annona senegalensisin Trypanasoma brucei brucei," Ann Trop. Med. Parasitol. 83, 527-534, 1989.

[12] E. A. Sofowora and C. O. Adewunmi, "Preliminary screening of some plant extracts for molluscidal activity," Planta Medica $39,57-65,1980$.

[13] M. Jacobson, R. E. Redfern and G. D. Mills. Naturally occurring insect growth regulators 11 . Screening of insect and plant extracts as juvenile hormone mimics. Lloydia 38 , 455-472, 1975.
[14] A. A. Mustapha, "Annona senegalensis Persoon: A Multipurpose shrub, its Phytotherapic, Phytopharmacological and Phytomedicinal Uses," International Journal of Science and Technology, 2(12), 862-865, 2013.

[15] C. B. Alawa, A. M. Adamu, J. O. Gefu, O. J. Ajanusi, P. A. Abdu, N. P. Chiezey, J. N. Alawa and D. D. Bowman, "In vitro screening of two Nigerian medicinal plants (Vernonia amygdalina and Annona senegalensis) for anthelmintic activity," Vet Parasitol. 113(1), 73-81, 2003.

[16] National Research Council. Guide for the Care and Use of Laboratory Animals, 8th ed.; The National Academies Press: Washington, DC, USA, 2011.

[17] A. G. Gornall, C. J. Bardwawill, and M. M. David, "Determination of serum proteins by means of the biuret reaction," The Journal of biological chemistry, 177(2), 751-766, 1949.

[18] K. A. Sinha, "Colorimetric assay of catalase. Annual Biochemistry, 47, 389-394, 1972.

[19] H. P. Misra and I. Fridovich, "The role of superoxide anion in the autoxidation of epinephrine and a simple assay for superoxide dismutase," J.Biol Chem., 247 (10), 3170 - 3175, 1972.

[20] K. Satoh, "Serum lipid peroxide in cerebrovascular disorders determined by a new colorimetric method," Clinica Chimica Acta, 90, 37-43, 1978.

[21] A. Kemp, J. M. Adrienne and K. V. Heijningen, "A colorimetric micro-method for the determination of glycogen in tissues," Biochem. J., 56, 646-648, 1954.

[22] D. S. Fredrickson, R. I. Levy and R. S. Lees, "Fat transport in lipoproteins - an integrated approach to mechanisms and disorders," New Engl. J. Med., 276, 215-225, 1967.

[23] P. J. Wright, P. D. Leathwood and D. T. Plummer, "Enzymes in rat urine: acid-phosphatase," Enzymologia, 42(6), 459-68, 1972.

[24] P. J. Wright, P. D. Leathwood and D. T. Plummer, "Enzyme in rat urine Alkaline phosphatase," Enzymologia 42, 317-327, 1972.

[25] O. S. Adeyemi and M. A. Akanji, "psidium guava leaf extract; effects on rats' serum homeostasis and tissue morphology," Comp. Clin. Pathol. 2010.

[26] M. T. Yakubu and Q. O. Nurudeen, "Effects of aqueous extract of Cnestis ferruginea (Vahl ex De Cantolle) root on paroxetine-induced sexual dysfunction in male rats," Asian Pac. J. Reprod., 1 (2):111-116, 2012.

[27] S. C. Joshi, N. Gulati and A. Gajraj, "Evaluation of toxic impacts of mancozeb on testis in rats," Asian J. Exp. Sci., 19(1), 73-83, 2005.

[28] R. L. Ksheerasagar, and B. B. Kaliwal, "Temporal effects of mancozeb on testes,accessory reproductive organs and biochemical constituents in albino mice," Envirot. Toxicol. Pharmacol. 15: 9-17, 2003.

[29] R. S. Gupta, R. Sharma, A. Sharma, A. K. Bhatnager, M. P. Dobhal, Y. C. Joshi and M. C. Sharma, "Effect of Alstonia scholaris bark extract on testicular function of wistar rats," Asian J. Androl., 4, 175-178, 2002. 
[30] P. Kamatchouing, Y. M. Fandio, T. Dimo, H. B. Jatsa, "Evaluation of androgenic activity of Zingiber officinale and Pentadiplandra brazzeana in male rats," Asian J. Androl. 4 299-301, 2002.

[31] P. Watcho, P. Kamtchouing, S. D. Sokeng, P. F. Moundipa, J. Tantchou, J. L. Essame and N. Koueta, "Androgenic effect of Mondia whitei roots in male rats," Asian J. Androl., 6, 269-272, 2004.

[32] N. Sofikitis and I. Miyagawa, "Secretary dysfunction of the male accessory genital gland due to prostate infections and fertility: A selected review of the literature," Jpn. Fertil. Steril. 36, 690-699, 1991.

[33] M. A. Adaikpoh and F. O. Obi, "Prevention of cadmium-induced alteration in rat testes and prostate lipid patterns by -tocopherol," Afr. J. Biochem. Res., 3 (10), 321-325, 2009.

[34] J. B. Kerr, R. A. Mayberry and D. C. Irby, "Morphometric studies on lipid inclusions in Sertoli cells during the spermatogenic cycle in the rat," Cell Tissue Res., 236, 699-709, 1984

[35] Y. Shima, K. Miyabayashi, S. Haraguchi, T. Arakawa, H. Otake, T. Baba, S. Matsuzaki, Y. Shishido, H. Akiyama, T. Tachibana, K. Tsutsui, K. Morohashi, "Contribution of Leydig and Sertoli cells to testosterone production in mouse fetal testes," Mol. Endocrinol. 27 (1), 63-73, 2013.

[36] I. S. Farooqi and S. O. Rahilly, "Monogenic Human Obesity Syndromes,”. Recent Prog. Horm. Res., 59, 409-424, 2004.
[37] F. Bustos-Obregon and J. R. Gonzalez, "Melatonin as protective agent for the cytotoxic effects of diazinon in the spermatogenesis in the earthworm Eisenia foetida," Ital. J. Anat. Embryol., 110 (2) 159-165, 2005.

[38] C. O. Ikediobi, V. L. Badisa, L. T. Ayuk-Takem, L. M. Latinwo and J. West, "Response of antioxidant enzymes and redox metabolites to cadmium-induced oxidative stress in CRL-1439 normal bliver cells," Int. J. Mol. Med., 14, 87-92, 2004.

[39] J. D. Eneman, R. J. Potis, M. Osier, G. S. Shukla, C. H. B. Lee and J. F. Chin, "Suppressed oxidant-induced apoptosis in cadmium adopted alveolar epithelial cells and its potential involvement in cadmium carcinogenesis," Toxicol., 147, 215-228, 2000.

[40] Z. Spolarics and J. X. Wu, "Role of glutathione and catalase in $\mathrm{H} 2 \mathrm{O} 2$ detoxification in LPS-activated hepatic endothelial and Kupffer cells," Gastroint. Liver Physiol., 273, G1304, 1997.

[41] V. Ramalingam and V. Vimaladevi,. "Effect of mercuric chloride on membrane-bound enzymes in rat testis," Asian J. Androl., 4, 309-311, 2002.

[42] S. Breton, P. T. S. Smith, B. Lui and D. Brown, "Acidification of the male reproductive tract by a proton pumping (H+)-ATPase," Natural Medicine, 2, 470-472, 1996.

[43] S. M. Cherry, P. A. Hunt and T. J. Hassold, "Cisplatin distrupts mammalian spermatogenesis, but does not affect recombination or chromosome segregation," Mutat. Res., 564, 115-128, 2004. 